\title{
REVIEW
}

\section{Oxidative stress in thyroid carcinomas: biological and clinical significance}

\author{
Rabii Ameziane El Hassani1', Camille Buffet ${ }^{2}$, Sophie Leboulleux ${ }^{3}$ and Corinne Dupuy² \\ 'Laboratory of Biology of Human Pathologies 'BioPatH', Faculty of Sciences, Mohammed V University of Rabat, Rabat, Morocco \\ 2UMR 8200 CNRS, Gustave Roussy and Paris Sud University, Villejuif, France \\ ${ }^{3}$ Department of Nuclear Medicine and Endocrine Oncology, Gustave Roussy and Paris Sud University, Villejuif, France
}

Correspondence should be addressed to C Dupuy: corinne.dupuy@gustaveroussy.fr

\begin{abstract}
At physiological concentrations, reactive oxygen species (ROS), including superoxide anions and $\mathrm{H}_{2} \mathrm{O}_{2}$, are considered as second messengers that play key roles in cellular functions, such as proliferation, gene expression, host defence and hormone synthesis. However, when they are at supraphysiological levels, ROS are considered potent DNAdamaging agents. Their increase induces oxidative stress, which can initiate and maintain genomic instability. The thyroid gland represents a good model for studying the impact of oxidative stress on genomic instability. Indeed, one particularity of this organ is that follicular thyroid cells synthesise thyroid hormones through a complex mechanism that requires $\mathrm{H}_{2} \mathrm{O}_{2}$. Because of their detection in thyroid adenomas and in early cell transformation, both oxidative stress and DNA damage are believed to be neoplasiapreceding events in thyroid cells. Oxidative DNA damage is, in addition, detected in the advanced stages of thyroid cancer, suggesting that oxidative lesions of DNA also contribute to the maintenance of genomic instability during the subsequent phases of tumourigenesis. Finally, ionizing radiation and the mutation of oncogenes, such as RAS and BRAF, play a key role in thyroid carcinogenesis through separate and unique mechanisms: they upregulate the expression of two distinct 'professional' ROS-generating systems, the NADPH oxidases DUOX1 and NOX4, which cause DNA damage that may promote chromosomal instability, tumourigenesis and dedifferentiation.
\end{abstract}

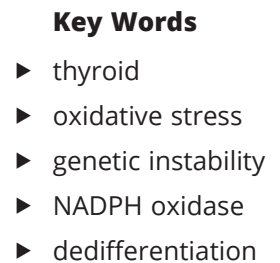

Endocrine-Related Cancer (2019) 26, R131-R143

\section{Introduction}

Reactive oxygen species, more commonly called ROS, are derived from oxygen and can be divided into two groups: free radicals, such as the superoxide anion $\left(\mathrm{O}_{2}{ }^{--}\right)$and hydroxyl anion $\left(\mathrm{OH}^{\bullet-}\right)$, and non-radical molecules, such as hydrogen peroxide $\left(\mathrm{H}_{2} \mathrm{O}_{2}\right)$. Cells produce ROS through a variety of enzymatic systems, including NADPH oxidases, xanthine oxidases, NO synthase, cytochrome P450 reductase and the mitochondrial electron transport chain. Inside cells, a balance exists between the production of ROS and their detoxification by non-enzymatic (ascorbate, glutathione) and enzymatic (catalase, superoxide dismutase 'SOD', glutathione peroxidase ' $\mathrm{GPx}^{\prime}$ and peroxiredoxins 'PRDX') antioxidant systems that finely control their concentrations and maintain cellular redox homeostasis (Veal et al. 2007, Lukosz et al. 2010) (Fig. 1). In several diseases, including cancer, the cellular redox balance is disrupted, leading to increases in the intra/ extracellular levels of ROS that overwhelm the antioxidant and detoxification proteins producing oxidative stress, which may promote tumour onset and numerous aspects 


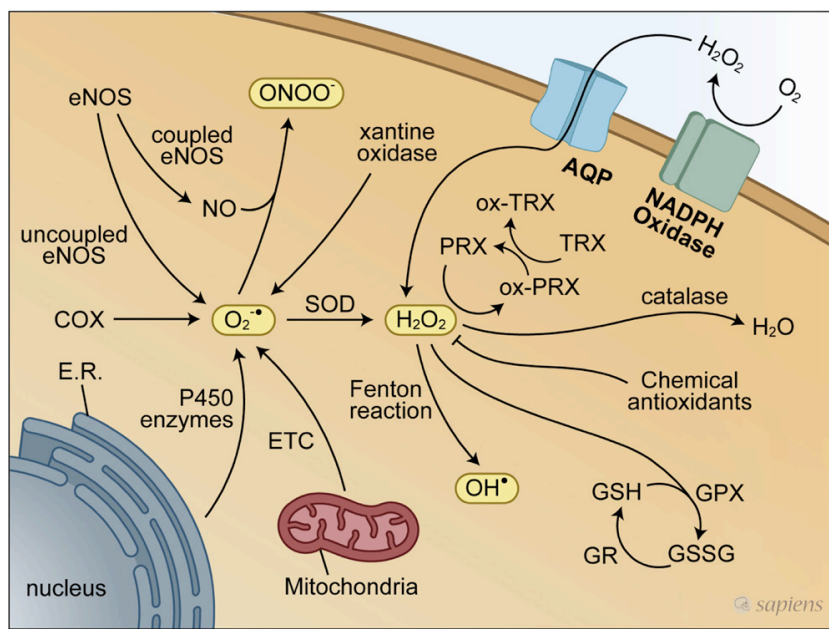

Figure 1

Cellular mechanisms of ROS generation and elimination. Schematic representation of redox homeostasis of eukaryotic cells. ROS-generating enzymatic systems: eNOS, endothelial nitric oxide synthase; COX cyclooxygenase; ETC, electron transport chain. Antioxidant enzymatic systems: SOD, superoxide dismutase; GPx, glutathione peroxidases; TRX, thioredoxine reductases; PRDX, peroxiredoxins. $\mathrm{ROS}: \mathrm{O}_{2} \cdot-$, superoxide anion; $\mathrm{OH}^{\cdot}$, hydroxyl radical; $\mathrm{H}_{2} \mathrm{O}_{2}$, hydrogen peroxide; $\mathrm{ONOO}$, peroxynitrite. Extracellular $\mathrm{H}_{2} \mathrm{O}_{2}$ can diffuse through specific membrane transporters such as aquaporins (AQP).

of progression towards a malignant phenotype, including angiogenesis, proliferation, epithelial-to-mesenchymal transition (EMT), invasion and apoptosis (Holmström \& Finkel 2014).

$\mathrm{H}_{2} \mathrm{O}_{2}$ is an important molecule. Because of its physicochemical properties, it is capable of serving as a messenger that carries a redox signal from the site of its generation to a target site. Among the various oxygen metabolites, $\mathrm{H}_{2} \mathrm{O}_{2}$ is considered the most suitable for redox signalling because it mediates signal transduction through the modification of specific cysteine residues located within redox-sensitive protein targets (Veal et al. 2007, Sies 2017). Additionally, $\mathrm{H}_{2} \mathrm{O}_{2}$ is a stable, mild oxidant that is electrically neutral; therefore, it can diffuse freely within and between cells, either passively or through specific membrane transporters such as aquaporins, and thus, initiates immediate cellular effects. The spatial distribution of $\mathrm{H}_{2} \mathrm{O}_{2}$ in cells is not uniform. There are substantial gradients, both between the extracellular to intracellular spaces and between the subcellular spaces (Antunes \& Cadenas 2000, Huang \& Sikes 2014). The ranges of $\mathrm{H}_{2} \mathrm{O}_{2}$ concentration during oxidative stress and during cellular responses have been estimated. The intracellular physiological level of $\mathrm{H}_{2} \mathrm{O}_{2}$ likely ranges from 1 and 10 and up to approximately $100 \mathrm{nM}$ (Sies 2017). At these low and moderate concentrations,
$\mathrm{H}_{2} \mathrm{O}_{2}$ can mimic growth factor stimulation and can activate cell proliferation (Burdon et al. 1995). For example, in response to growth factors, a transient increase in the levels of intracellular $\mathrm{H}_{2} \mathrm{O}_{2}$, is able to oxidize catalytic cysteines in protein tyrosine phosphatases, which leads to their inactivation and a consequent increase in tyrosine phosphorylation-dependent signalling (Meng et al. 2002).

The endocrine function of the thyroid gland is thyroid hormone synthesis $\left(\mathrm{T}_{3}\right.$ and $\mathrm{T}_{4}$ ), and during this process, follicular thyroid cells called 'thyrocytes' produce a significant amount of $\mathrm{H}_{2} \mathrm{O}_{2}$ within the follicular lumen, or colloid, at the apical membrane of thyrocytes (Carvalho \& Dupuy 2017) (Fig. 2). Thus, owing to the oxidative nature of thyroid hormone synthesis, the thyroid gland remains one of the most vulnerable organs to the deleterious effects of oxidative stress. Therefore, thyrocytes have the difficult task of tightly regulating the equilibrium between ROS production and scavenging (Kohrle \& Gartner 2009).

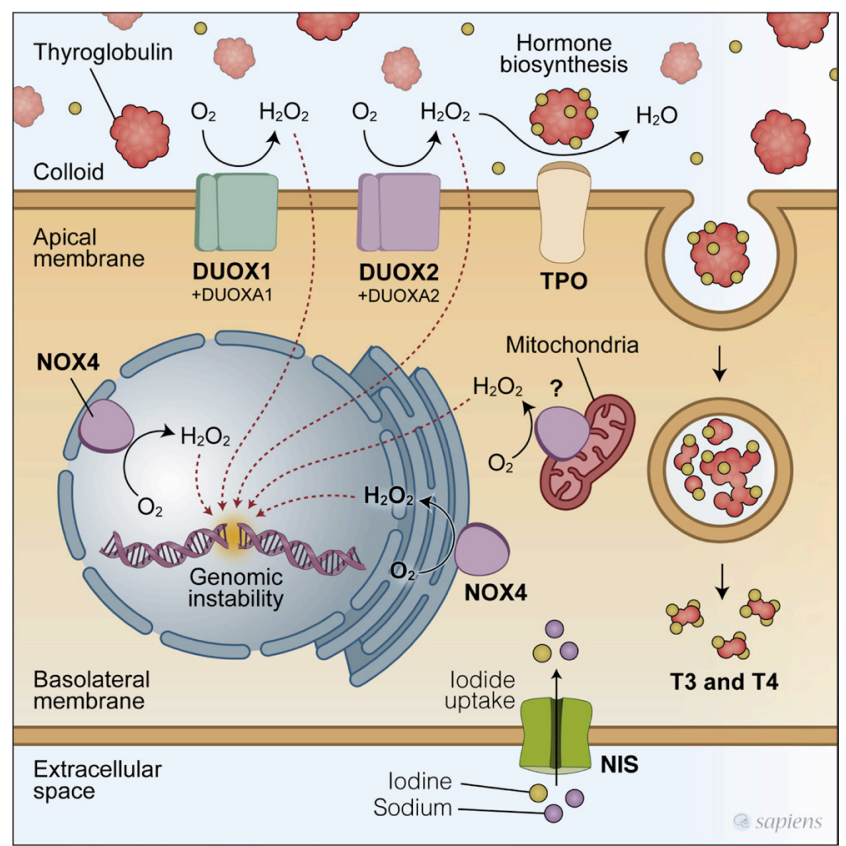

\section{Figure 2}

Hypothetical model of the role of $\mathrm{H}_{2} \mathrm{O}_{2}$-generating NADPH oxidases in DNA damage in the thyroid. At the apical membrane of follicular cells, thyroid peroxidase (TPO) uses $\mathrm{H}_{2} \mathrm{O}_{2}$ locally produced by DUOX2 to catalyse hormone biosynthesis. The role of DUOX1 in the thyroid remains to be established. However, it could compensate for DUOX2 deficiency. In a pathological context, $\mathrm{H}_{2} \mathrm{O}_{2}$ produced by DUOXs can diffuse through the apical membrane of thyrocyte and could reach the nucleus directly or via redox signalling pathways that might activate the intracellular NADPH oxidase 4 (NOX4), which is detected in the nucleus and in the endoplasmic reticulum. The presence of NOX4 in the perinuclear region might increase the nuclear oxidative stress and promote DNA damage and genomic instability. (c) 2019 Society for Endocrinology Published by Bioscientifica Ltd. Printed in Great Britain 
In this context, the importance of some selenium (Se)-containing antioxidative enzymes and proteins has been described. These proteins are expressed in thyrocytes, are partially secreted into the colloid lumen and mainly belong to the glutathione peroxidase (GPx) and thioredoxin (Txn) reductase (TxnRd) families (Kohrle \& Gartner 2009). Together with GPx, catalase, as well as the peroxiredoxins (PRDX), also protect thyroid cells against $\mathrm{H}_{2} \mathrm{O}_{2}$ (Kim et al. 2000, Nicolussi et al. 2017).

After establishing the critical role of oxidative stress in thyroid tumourigenesis, this review will assess how ROS are involved in genetic instability, which contributes to the initiation and development of tumours. This review will also focus on two ROS-generating systems: the NADPH oxidases DUOX1 and NOX4 and their roles in DNA damage, senescence and thyroid dedifferentiation.

\section{Oxidative stress and thyroid carcinomas}

Since oxidative stress is associated with the occurrence and development of several cancers, prospective studies have investigated the relationship between the oxidative stress parameters and the serum profiles of thyroid cancer patients and controls in order to identify one or more markers to distinguish thyroid cancer from different types of benign thyroid disease. The oxidative stress parameters were determined by measuring the total antioxidant status (TAS) and the total oxidant status (TOS), and the oxidative stress index (OIS) was calculated as the ratio of TOS to TAS. Analysis of the oxidative status of sera showed that oxidant levels were significantly increased in patients with thyroid cancer compared to controls and that antioxidant levels were lower in patients with thyroid cancer than in healthy controls (Wang et al. 2011). An increase in the oxidative stress in the blood of patients affected by thyroid cancer was also detected by electronic paramagnetic resonance measurements, which were significantly altered following a thyroidectomy (Metere et al. 2012). In addition, a high concentration of malondialdehyde (MDA), an oxidized lipid-derived aldehyde, was found in the blood of patients affected by thyroid cancer (Akinci et al. 2008, Geric et al. 2016), and this was associated with a decrease in the antioxidative capacity of whole blood. All these results suggest that there is a relationship between oxidative stress and the presence of thyroid cancer. However, it remains unclear how a tumour of a few $\mathrm{cm}^{3}$ can impact the oxidative status of serum, and whether these changes are risk factors for thyroid cancer or the consequence of its occurrence. The role of oxidative stress in thyroid cancer was characterized by analysing the expression of two selenium antioxidant molecules, glutathione peroxidase (GPx1) and thioredoxin reductase (TrxR1) in thyroid cancer cells. Decreased expression of both proteins was observed in cancer cells compared to healthy cells and was associated with an increased level of free radicals in the tumour tissue (Metere et al. 2018). The expression of catalase was also dramatically decreased in human thyroid tumours compared with normal thyroid tissue (Hasegawa et al. 2002, 2003). These findings illustrate the imbalance of the oxidant/antioxidant system in thyroid cancer tissue.

In addition, the expression of peroxiredoxins PRDX1 and PRDX6 was repressed in papillary thyroid carcinomas (Nicolussi et al. 2014), but conversely, increased expression of PRDX5 was reported in Hürthle cell carcinoma, a type of papillary thyroid carcinoma (PTC). However, the role of PRDXs in cancer remains controversial (Nicolussi et al. 2017).

\section{Oxidative DNA damage in thyroid carcinomas}

Oxidative stress is considered to be a cause of DNA damage, which is in turn an initial step of tumourigenesis (Krohn et al. 2007). The direct interaction of ROS with DNA can lead to the formation of oxidative DNA base lesions, including abasic sites, single-strand DNA breaks, sugar moiety modifications, deaminated bases and adducted bases (Sedelnikova et al. 2010). If unrepaired, these DNA lesions could change some of the genetic information, consequently affecting genome integrity by causing mutagenesis and by inhibiting both replication and transcription. Despite the reported mutagenic and carcinogenic roles of oxidative DNA damage, it is difficult to assess the mutational specificity and the clinical significance of each individual oxidative DNA modification because of the number of these oxidative modifications and their derivative products. Among the four DNA bases, guanine is the preferential target for oxidation because it has the smallest redox potential (Boiteux et al. 2017); thus, guanine oxidation is considered to be a useful marker of oxidative DNA damage during carcinogenesis (Kasai 1997). The oxidized form of guanine, 8-oxo-2'-deoxyguanosine (8-oxo-dG), is repaired by the base excision repair (BER) pathway, a multistep process that requires the DNA repair enzyme 8-oxoguanine DNA glycosylase (a domain of the protein $\mathrm{N}$-glycosylase/DNA lyase, encoded by OGG1) (Sedelnikova et al. 2010). 8-Oxo-dG is frequently studied as a potent mutagenic oxidative base because of its tendency to mispair with an adenine base; thus, GC-to-AT transitions and GC-to-TA transversions are the
C) 2019 Society for Endocrinology Published by Bioscientifica Ltd. Printed in Great Britain 
most prominent oxidative mutations (Wang et al. 1998). In addition, oxidative stress can oxidize the intracellular dGTP (deoxyguanosine triphosphate) pool, which mispairs with adenine during replication and results in a mutation (Scott et al. 2014). $\mathrm{H}_{2} \mathrm{O}_{2}$ itself is almost inert towards DNA; however, the $\mathrm{H}_{2} \mathrm{O}_{2}$-derived hydroxyl radicals $\left(\mathrm{OH}^{-}\right)$are actively involved in the oxidation of DNA. This is closely linked with the participation of redox-active metals, such as iron, that participate in the Fenton reaction and generate reactive hydroxyl radicals. Although iron regulation ensures that there is no free intracellular iron, under stress conditions, an excess of ROS releases 'free iron' from iron-containing molecules (Valko et al. 2006).

In mouse models, the levels of oxidative DNA damage in the thyroid gland were higher than those in any other organ, with high levels of thyroid OGG1 mRNA expression (Maier et al. 2006). Increased nuclear levels of 8-oxo-dG were found in both benign (human follicular adenomas or FTAs) and malignant (follicular (FTC) and PTC) lesions in comparison with matched normal tissue (Young et al. 2010, Karger et al. 2012); this most likely reflects the deleterious impact of a long-term exposure to chronic oxidative stress that is observed during thyroid malignancy. Interestingly, an investigation of the link between $B E R$ gene expression and human thyroid malignancy showed a reduction in OGG1 expression in FTC compared to FTA (Karger et al. 2012). TCGA data analysis highlights a downregulation of the expression level of OGG1 in papillary thyroid tumours with a high level of MAPK1 expression, which reflects the activation of the MAPK signalling pathway (Fig. 3A) (C Dupuy, unpublished observations), supporting the potential contribution of oxidative DNA damage to the thyroid dedifferentiation mechanism, which may lead to radioresistance.

However, compared to other tumours, thyroid tumours show a low overall density of somatic mutations, suggesting that DNA repair has an important role in the maintenance of DNA integrity. Distinct signatures that are associated with deficiencies in DNA repair pathways such as HR (homologous recombination), MMR (DNA mismatch repair) and NER (nucleotide excision repair) have been found in various cancers, but no mutational signature has been attributed to impaired BER activity or to oxidative DNA lesions (Helleday et al. 2014). This suggests that the signatures might reflect a strong, intermittent process that temporarily overwhelmed the DNA repair capacity or that provoked error-prone repair (Tubbs \& Nussenzweig 2017). Both inter- and intra-pathway complementation exists in the repair mechanisms of oxidative base damage (Berquist $\&$ Wilson 2012). The majority of driver mutations in the BRAF and NRAS oncogenes occur at A/T pairs (Hodis et al. 2012). It has been suggested that error-prone repair using
A

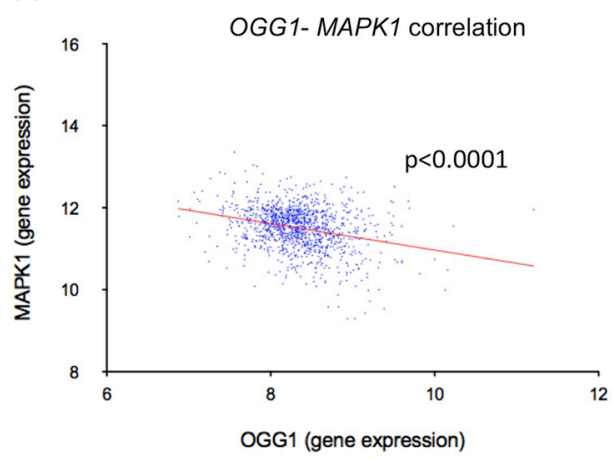

C

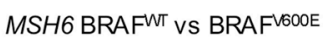

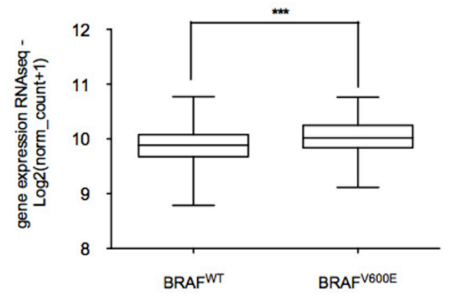

B

MSH2 BRAFWT VS BRAFVGOOE

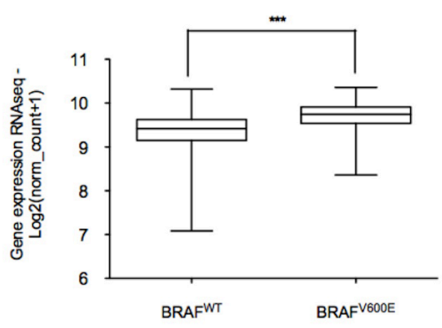

D POLH BRAFWT VS BRAFVGOOE

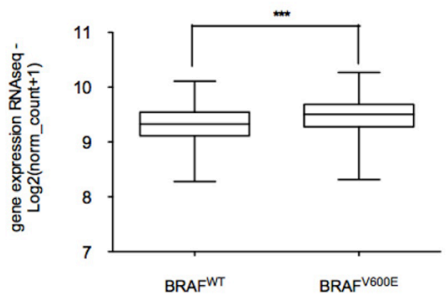

Figure 3

POLH, MSH2 and MSH6 expression levels are significantly increased in papillary thyroid cancer (PTC) harbouring BRAFV600E mutation. A homogeneous cohort of 390 PTCS (170 BRAFWT PTCs and 220 BRAFV600E PTCs) were included in this analysis. Correlative analysis between OGG1 gene expression and MAPK1 gene expression (A) Correlative analysis between MSH2 mRNA (B) or MSH6 mRNA (C) or POLH mRNA levels (D) and BRAFV600E mutation in 390 PTCs. Values are mean \pm S.E. ${ }^{*} * * P<0.0001$. ERK, extracellular signal-regulated kinase. 
the translesion DNA polymerase eta (POL $)$ contributed to these driver mutations, which are expressed in 40-60\% (for BRAF) and 6\% (for NRAS) of PTCs, respectively. Notably, the MSH2-MSH6 heterodimer, which plays a fundamental role in the recognition of base pair mismatches and the signalling of mismatch repair (MMR), acts in concert with POL $\eta$ to remove complex DNA lesions induced by oxidative stress in human cells (Zlatanou et al. 2011). Moreover, investigations have suggested that oxidative stress caused by inflammation may be partly responsible for mutations of the BRAF gene (Martinez-Cadenas et al. 2011). Interestingly, in TCGA data, POLH, MSH 2 and MSH6 expression levels are significantly increased in PTCs with a BRAF mutation, suggesting that this complex might be involved in an alternative DNA repair pathway that compensates for the decrease in OGG1 in these tumours (Fig. 3B, C and D) (C Dupuy, unpublished observations). In addition, this complex might be the origin of the oncogenic mutations found in PTCs.

In some circumstances, clustered oxidative DNA lesions, which are difficult to resolve, can lead to the formation of DNA double-strand breaks (DSBs) (Sedelnikova et al. 2010). DSBs can promote genetic instability and chromosomal rearrangements (Richardson $\&$ Jasin 2000). Interestingly, exposure of human thyroid cells to $\mathrm{H}_{2} \mathrm{O}_{2}$ induces DSBs (Driessens et al. 2009, Ameziane-El-Hassani et al. 2010) and, consequently, an oncogenic RET/PTC rearrangement (Ameziane-El-Hassani et al. 2010), which is an early event in thyroid follicular cell transformation (Viglietto et al. 1995). Upon $\mathrm{H}_{2} \mathrm{O}_{2}$ exposure, thyroid cells increase the expression of the antioxidant response genes and the inhibition of this response markedly decreases cellular resistance to $\mathrm{H}_{2} \mathrm{O}_{2}$ and promotes DNA damage (Versteyhe et al. 2013); this corroborates that the weakening of the detoxification process might favour the mutagenic effects of $\mathrm{H}_{2} \mathrm{O}_{2}$.

From an experimental point of view, the phosphorylated form of the histone $\operatorname{H2AX}(\gamma$-H2AX) is considered a useful marker of both DNA lesions and the DNA damage response or 'DDR' (Valdiglesias et al. 2013). Immunohistochemical staining analysis showed that $\gamma$-H2AX was increased in PTC compared to normal adjacent tissue and to nodular goitre (Hu et al. 2014). Moreover, the nuclear immunostaining of 53BP1, a specific marker of DNA DSBs, reveals its presence in thyroid tumours with intense staining within the nucleus of high-grade thyroid tumours (Nakashima et al. 2008); thus, suggesting a strong involvement of DNA DSBs and defects in their repair in the evolution of thyroid cancers.

\section{Thyroid ROS-generating systems: the NADPH oxidases and the mitochondria}

In the last decade, the involvement of NADPH oxidases, which produce ROS as their primary and sole function, has become of particular interest in thyroid malignancy. Unlike other enzymes, such as xanthine oxidase, cytochrome $\mathrm{P} 450$ and those of the mitochondrial electron transport chain, which are capable of producing ROS, NADPH oxidases produce $\mathrm{H}_{2} \mathrm{O}_{2}$ and/or $\mathrm{O}_{2}{ }^{-}$in a tightly controlled manner and act locally in the redox control of specific signalling pathways (Ameziane-El-Hassani et al. 2016). The other enzymes listed above produce ROS as an accidental by-product of their primary catalytic pathways. In this case, the production is neither specific nor transient, which are the two conditions that define signalling. Until the early 2000s, the only known NADPH oxidase was the phagocyte NADPH oxidase, which plays a key role in innate immunity by generating and releasing large amounts of superoxide $\left(\mathrm{O}_{2}{ }^{--}\right)$into the phagosomes. It is composed of a membranous and heterodimeric flavocytochrome including gp91phox, the catalytic core and p22phox. The discovery of six homologs of gp91phox, which is now called NOX2, over the past 18 years, has given rise to a new interest in this type of enzymes. The six other NOXs that are now identified are NOX1, NOX3, NOX4, NOX5, DUOX1 and DUOX2.

The thyroid gland expresses three NADPH oxidases: DUOX1, DUOX2 and NOX4. The DUOX enzymes were first identified in the thyroid gland as $\mathrm{H}_{2} \mathrm{O}_{2}$-generating systems associated with thyroperoxidase (TPO), which is the enzyme that catalyses thyroid hormone biosynthesis at the apical surface of thyrocytes (Dupuy et al. 1999, De Deken et al. 2000) (Fig. 2).

Each DUOX requires maturation factors (DUOXA1 and DUOXA2) to exit from the endoplasmic reticulum (ER) and to reach the plasma membrane, where they form a stable complex; this is a prerequisite for their $\mathrm{H}_{2} \mathrm{O}_{2}$ producing activity (Grasberger \& Refetoff 2006). Different phosphorylation pathways regulate the enzymes through TSH: DUOX1 is activated by protein kinase A (Gs-PKA pathway); DUOX2 activation occurs through protein kinase C (Gq-phospholipase C pathway) and calcium is the primary activator for both of these enzymes (Rigutto et al. 2009).

In addition to the catalytic core, which contains six transmembrane domains and is common among their five counterparts (NOX1-5), the two DUOXs have an $\mathrm{N}$-terminal peroxidase-like ectodomain whose structure, which is controlled by an intramolecular disulphide 
bridge, is crucial for both the functioning and targeting of DUOXs (Carre et al. 2015, Louzada et al. 2018). A functional interaction between DUOX and TPO, which is promoted by $\mathrm{H}_{2} \mathrm{O}_{2}$ itself, regulates the level of extracellular $\mathrm{H}_{2} \mathrm{O}_{2}$ (Fortunato et al. 2010, Song et al. 2010). This association at the plasma membrane might have a role in limiting the diffusion of $\mathrm{H}_{2} \mathrm{O}_{2}$ into the cell and thereby protecting cells from oxidative damage. Thus, in addition to leading to the sustained proliferation of thyroid cells due to hypothyroidism, the absence of TPO might also promote cancer development. This chemoprotective effect of TPO could explain the severity of the symptoms associated with congenital goitres and the frequent evolution of this condition to nodule and tumour formation in patients who have a defect in TPO. The role of $\mathrm{H}_{2} \mathrm{O}_{2}$ in thyroid tumourigenesis might be reinforced by the observation that TPO expression and activity are low, or even undetectable, in thyroid cancer tissue. Analysis of TCGA data shows that in the case of PTC, the expression of DUOX1, DUOX2 and their maturation factors is associated with tumour differentiation; lower expression is observed in tumours with the BRAFV600E mutation, which are less differentiated than other PTC tumours (Cancer Genome Atlas Research Network 2014). Although the expression of DUOX1 and DUOX2 is positively correlated to thyroid carcinoma (Lacroix et al. 2001), this finding does not imply that each DUOX has the same level of involvement in the early stages of tumour development.

The thyrocytes also express the NADPH oxidase NOX4. The physiological function of NOX4 in the thyroid is unknown. No thyroid dysfunction has yet been described for NOX4-knockout animal models. This NOX, which was first identified in the kidney, is ubiquitously expressed at high levels, which is in contrast to the other NOX proteins. However, the effects of NOX4-derived ROS appear to be cell type dependent, probably owing to the distinct redox-sensitive targets that are affected in each cell type. NOX4 is the only NADPH oxidase with constitutive ROS-generating activity that depends directly on its gene expression. The enzymatic activity strongly depends on the heterodimerization of NOX4 with the membrane protein $\mathrm{p} 22^{\text {phox }}$ but not on cytosolic subunits, such as NOX2. NOX4 is active not only at the plasma membrane but also in different intracellular compartments and organelles, including the ER, mitochondria and nucleus (Ameziane-El-Hassani et al. 2016) (Fig. 2). The presence of NOX4 in the perinuclear region might affect the level of oxidative stress in the nucleus and thus contribute to oxidative modifications and damage. NOX4 expression is increased in thyroid cancers and is particularly high in
PTC (Weyemi et al. 2010). Moreover, unlike DUOX, NOX4 expression is controlled by TSH at the transcriptional level (Weyemi et al. 2010). An association has been found between high TSH levels and an increased risk of the development of malignant thyroid nodules (Haymart et al. 2009, Tam et al. 2018). In this case, TSH's potential effect on cancer cells would require the maintenance of their receptor's expression. As an ROS-generating system controlled by TSH, NOX4 could be contributing to a mechanism that drives this association.

Despite its ability to generate ROS during respiratory chain function, the causal relationship between mitochondria as a source of oxidative stress and thyroid tumourigenesis does not seem to be well established (Coelho et al. 2018). Mitochondrial ROS are produced by the leakage of electrons from complexes I and III of the electron transport chain (ETC) during oxidative phosphorylation, an important process that generates ATP. However, the $\mathrm{O}_{2}{ }^{\cdot-}$ production that occurs through this mechanism does not appear to be a regulated process. Several studies have now demonstrated that NOX4 is localized in the mitochondria and produces ROS under pathological conditions (Block et al. 2009). An abnormal accumulation of functionally defective mitochondria was reported in oncocytic/Hürthle thyroid carcinomas (Coelho et al. 2018). In this context, the decreased enzymatic activity of complexes I and III of the ETC was correlated with high ROS generation by this organelle (Bonora et al. 2006). Interestingly, these results could be related to a recent study that showed that OXPHOS-driven ATP production in the mitochondria controlled NOX4-derived ROS production. Under normal conditions, ATP binds allosterically to NOX4 through Walker A ATP-binding domain, keeping NOX4-derived ROS production low. However, certain cellular events, such as cancer, which switch ATP production to aerobic glycolysis in the cytosol, lead to a reduction of the ATP levels in the mitochondria, thereby relieving this inhibition and leading to NOX4derived ROS production (Shanmugasundaram et al. 2017).

\section{Risk, causes and dedifferentiation of thyroid cancers: involvement of NADPH oxidases DUOX1 and NOX4}

Ionizing radiation (IR) can cause various delayed effects in cells, including genomic instability that leads to the accumulation of gene mutations and chromosomal rearrangements, which are thought to play a pivotal role in radiation-induced carcinogenesis. The persistence of such effects in the progeny of cells has profound 
implications for long-term health risks, including the emergence of a secondary malignancy. The thyroid gland is one of the most sensitive organs to the carcinogenic effects of IR. The risk of thyroid tumours is maximal when exposure occurs at a young age, and it increases linearly with the radiation dose (Sinnott et al. 2010). More than $90 \%$ of these cancers are papillary tumours, which present with an RET/PTC chromosomal rearrangement in $70 \%$ of cases. The mechanisms by which radiation exposure is internalized and leads to delayed DNA breakage are poorly understood. Hypoxia and antioxidant therapy reduce the delayed X-ray-induced effects, suggesting that radio-induced oxidative stress plays a significant role in determining the susceptibility of irradiated cells to genetic instability (Robbins \& Zhao 2004). To analyse how ROS cause persistent instability, we recently investigated the mechanism by which IR induces the generation of ROS several days after irradiation. The results showed that the NADPH oxidase DUOX1 promoted the long-term persistence of oxidative stress after exposure to irradiation (Ameziane-El-Hassani et al. 2015) (Fig. 4). Abrogation of DUOX1 expression resulted in a significant decrease in post-irradiation DNA damage in thyroid cells, indicating that DUOX1-dependent $\mathrm{H}_{2} \mathrm{O}_{2}$ production plays a key role in persistent radio-induced DNA damage. This damage was observed several days after irradiation and was materialized by the presence of $\gamma \mathrm{H} 2 \mathrm{AX}$ and 53BP1 nuclear foci in G1-phase cells. These foci could have formed following a replicative stress that induced chromosomal damage that bypassed mitosis and was then transmitted to daughter cells. Indeed, one of the recognized sources of replication stress is oxidative DNA damage, which creates physical barriers to the progression of the replication fork. In addition, ROS can also affect, via redox mechanisms, the enzymes involved in the metabolism of nucleotides that are essential for both the synthesis and repair of DNA and/or can inhibit the enzyme systems involved in replication or in the repair of DSBs. There are genomic regions that are prone to replication stress-induced DSBs. These regions, called 'common fragile sites' (CFS), are sensitive readouts for replication stress (Zeman \& Cimprich 2014). RET and CCDC6, the two genes involved in the oncogenic translocation of RET/PTC1, are both located in CFS (Gandhi et al. 2010). The overexpression of DUOX1 in radio-induced thyroid tumours suggests that this NADPH oxidase may contribute to chronic oxidative stress, thereby promoting genomic instability and tumourigenesis (Ameziane-El-Hassani et al. 2015). Replication stress and oxidative stress are intertwined and reinforce each other in the driving of genomic instability (Xu et al. 2014). Moreover, a high level of DUOX1 protein was also observed in some sporadic thyroid tumours, suggesting that high levels of DUOX1 might be required for thyroid tumourigenesis. Notably, DUOX1 was not differentially expressed in sporadic PTCs that occurred in the absence of previous radiation exposure or in radiationinduced PTCs from the Chernobyl Tissue Bank (Detours et al. 2007).

PTCs are the most frequent histological type of human thyroid carcinoma and account for approximately $85 \%$ of all thyroid carcinomas. PTCs include several tumour types that have mutually exclusive mutations of genes that

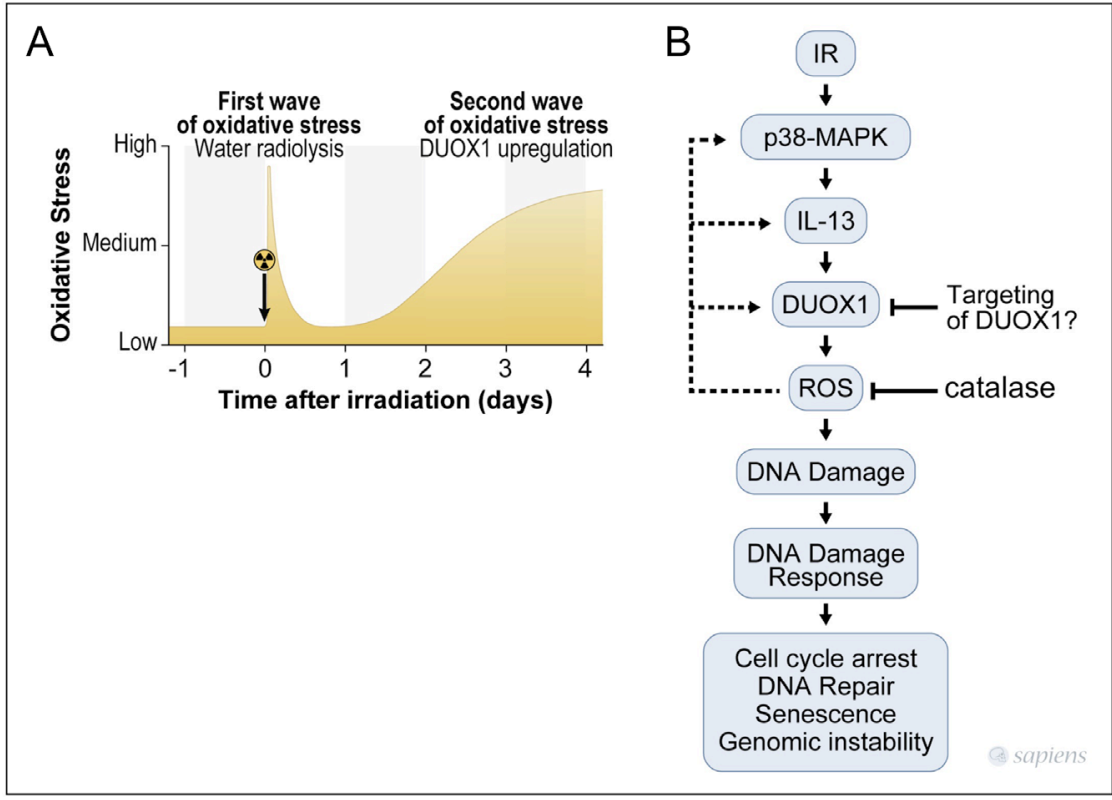

\section{Figure 4}

Consequences of increased DUOX1 expression after irradiation of thyroid cells. (A) X-ray irradiation of thyroid cells elicits two temporally separated phenomena: first, an oxidative burst mediated by radiolysis of water, and, second, a persistent oxidative stress mediated by DUOX1 upregulation. (B) Irradiation leads to a delayed increased DUOX1 expression through activation of p38 MAPK. This regulation is controlled via IL-13. Radio-induced DUOX1-dependent $\mathrm{H}_{2} \mathrm{O}_{2}$ production plays a key role in persistent $D N A$ damage whose consequences can be, in particular, induction of genetic instability that promotes the formation of chromosomal rearrangements. (c) 2019 Society for Endocrinology Published by Bioscientifica Ltd. Printed in Great Britain 
encode effectors that signal through the MAPK pathway (Fagin \& Wells 2016). The BRAFT1799A point mutation, encoding the BRAFV600E oncogenic constitutively active protein kinase, accounts for $60 \%$ of these mutations; this is followed by RAS mutations (15\%) and by chromosomal rearrangements that lead to illegitimate expression of the kinase domains of BRAF or receptor tyrosine kinases, such as RET, NTRK and ALK (12\%). Clinically, BRAFV600E is associated with a more extensive disease, a higher rate of recurrence and decreased survival (Xing 2013). In vivo and in vitro studies have demonstrated the key role of BRAFV600E in tumour progression and in the formation of the most undifferentiated stages. It is not fully understood how the expression of mutant BRAF contributes to the aggressive character of PTCs, including in particular an alteration of the expression of genes involved in the metabolism of iodine, which is essential for the synthesis of hormones. Iodine uptake is catalysed by the sodiumiodide symporter (NIS), a membrane glycoprotein located in the basolateral membrane of thyrocytes. This property has been used for many years in therapeutics that treat thyroid cancer with radioactive iodine-131. However, some patients are initially refractory to this therapy or may become refractory to this therapy because of a loss of NIS expression, which occurs fairly early during oncogenesis. An understanding of the mechanisms that underlie this loss of expression is important for the design of a therapeutic strategy that can correct for this anomaly. The inhibition of the mitogen-activated protein kinase (MAPK) pathway is not always efficient, in particular, for the redifferentiation of radioiodine-resistant tumours, which suggests that other compensatory mechanisms contribute to BRAFV600E adaptive resistance (Ho et al. 2013). Several studies have shown an important role for transforming growth factor B1 (TGF- $\beta$ ) in this process. TGF- $\beta$ is overexpressed in thyroid malignancies (Matoba et al. 1998, Vasko et al. 2007). BRAFV600E expression induces the production of TGF- $\beta 1$, which leads to a TGF- $\beta$-driven autocrine loop that mediates, at least in part, the effects of the BRAFV600E oncoprotein; it particularly mediates the decreased expression of NIS (Riesco-Eizaguirre et al. 2009) and the promotion of cell migration, invasiveness and EMT (Knauf et al. 2011). Recently, we showed that NOX4 is upregulated by BRAFV600E via a TGF- $\beta$-Smad3-dependent pathway in thyroid cancer cells and that NOX4-dependent ROS generation has a critical role in the NIS repression that is induced by mutant BRAF (Azouzi et al. 2017) (Fig. 5); this corroborated previous studies suggesting that the SLC5A5 gene promoter activity that encodes the NIS symporter is dependent on the redox state of the cell
(Puppin et al. 2004). The reversible nature of the reduced expression of the SLC5A5 gene by NOX4 suggests that an epigenetic mechanism may be active that may involve a redox-sensitive control mechanism for the recruitment of silencing complexes that contain DNA methyl transferase and histone deacetylases (HDACs) to the promoter region.

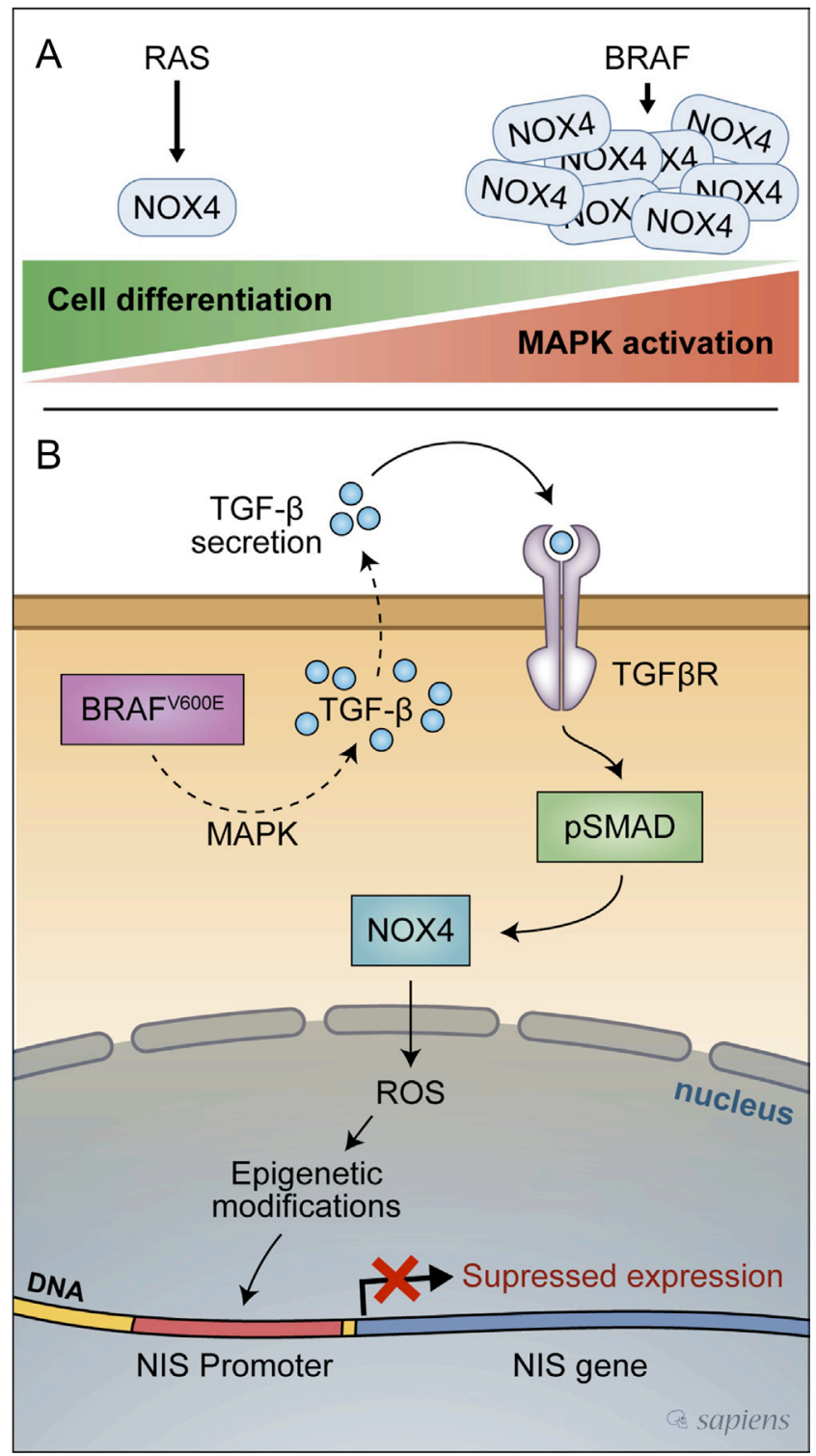

\section{Figure 5}

Oncogenic BRAF-dependent regulation of NOX4. (A) Mutant RAS and BRAF activate mitogen-activated protein kinase (MAPK) signalling at different degree with high MAPK signalling and NOX4 expression in tumours driven by BRAF compared to that driven by RAS. This was inversely correlated with cell differentiation. (B) Proposed model for BRAFV600E mediated NIS repression in thyroid cancer cells. BRAFV600E increases TGF- $\beta$ synthesis and secretion via the MAPK signalling pathway. NOX4 is upregulated by BRAFV600E in a TGF- $\beta$-Smad3-dependent pathway and NOX4-derived ROS participate to NIS repression. The mechanism could involve redoxsensitive epigenetic modifications. 
The link between BRAFV600E and NOX4 was confirmed by a comparative analysis of NOX4 expression in human (TCGA) and mouse thyroid cancers. The level of NOX4 expression in human and murine $B R A F^{V 600 E}$-mutated thyroid tumours is inversely correlated with thyroid differentiation; this suggests that genes other than NIS that are involved in thyroid differentiation might be silenced by a mechanism controlled by NOX4-derived ROS (Azouzi et al. 2017). However, further investigations are needed to determine whether this increase in NOX4 expression is a cause or a consequence of the thyroid dedifferentiation process. Moreover, tumour-associated mutant p53 proteins enhance NOX4 expression in both TGF- $\beta$-dependent and TGF- $\beta$-independent processes in human breast and lung epithelial cells (Boudreau et al. 2014). Inactivation of $\mathrm{p} 53$ has been considered a hallmark of advanced thyroid tumours (Fagin et al. 1993). TP53 mutations are highly prevalent in ATCs, which have a higher mutation burden. This might be related to an increase in NOX4-induced DNA damage via ROS production, in addition to the loss of the canonical function of ATM kinase in some of these tumours (Landa et al. 2016) as ATM is required for successful DNA repair (Cremona \& Behrens 2014).

In addition, regardless of its level of expression, NIS must be sufficiently expressed at the plasma membrane to mediate effective RAI uptake. Several studies have demonstrated that NIS is mis-localised to the cytoplasm in thyroid cancers (Dohan et al. 2001, Smith et al. 2013). At the present time, it is unknown whether ROS affect NIS trafficking. However, we recently observed that NOX4 inactivation increased the cell surface expression of NIS in two BRAF-mutant thyroid cell lines, suggesting that the NOX4-derived ROS might also impact the signalling pathways involved in NIS trafficking (Azouzi et al. 2017).

Thyroid tumour-associated oncogenes (BRAFV600E, H-RASV12, RET/PTC1 and RET/PTC3) have been shown to trigger permanent cell cycle arrest, known as oncogeneinduced senescence (OIS), in human thyroid cells (Vizioli et al. 2011, 2014, Weyemi et al. 2012, Bellelli et al. 2018). Severe or irreparable DNA damage is involved in the proliferative arrest and induces a DNA damage response that precedes senescence. Initially, senescence acts as a barrier to tumourigenesis, and a bypass of senescence at later stages might enable cellular transformation and tumour progression. Immunohistochemical analysis of human thyroid tumours has revealed high expression levels of senescence markers during the early stages of thyroid tumourigenesis that are lost during the later stages, which provides an indirect demonstration that senescence evasion is a mandatory step during thyroid tumourigenesis (Vizioli et al. 2011). Conditional expression of H-RASv12 in human thyroid cells positively regulated NOX4-derived $\mathrm{H}_{2} \mathrm{O}_{2}$, which induced DNA damage that led to replicative stress and subsequently to senescence (Weyemi et al. 2012). Analysis of human PTCs (TCGA) showed that the NOX4 expression level was correlated with ERK activation (Azouzi et al. 2017). Thus, the level of NOX4 expression in thyroid tumours may depend on the level of MAPK activation, and the expression level may thus contribute to the establishment of senescence. However, senescence-associated ROS may also promote the emergence of pretumoural cells through mutagenicity of ROS and thus may explain why some tumours, such as $B R A F^{V 600 E}$-mutated thyroid tumours, overexpress NOX4.

\section{Conclusion and perspectives}

Oxidative stress is a risk factor associated with thyroid tumourigenesis. Until recently, the sources of ROS were not defined. The identification of the NADPH oxidases DUOX1 and NOX4 as sources of ROS in thyroid tumourigenesis has opened the way for research concerning their respective roles in the mechanisms that lead to genetic instability and to dedifferentiation. The dysregulation of their expression and activity can threaten DNA stability and, therefore, influence cell fate. This dysregulation may have far-reaching health implications. DUOX1 promotes persistent DNA damage after irradiation, which is also a risk factor for thyroid cancer. Further studies are now needed to determine how DUOX1 is involved in radiocarcinogenesis and, in particular, what is its potential role in DNA break formation at chromosomal fragile sites, which are hotspots for chromosomal translocations such as RET/PTC. NOX4 also seems to have a critical function in thyroid tumourigenesis, particularly in PTC harbouring the BRAFV600E mutation, which are associated with cell dedifferentiation and radioiodine refractoriness. The mechanisms that may connect NOX4 to the dedifferentiation process need to be studied in depth, but NOX 4 may become a new potential therapeutic target due to its role in NIS repression.

The absence or loss of radioactive iodine (RAI) uptake in thyroid cancer cells is a major challenge for the treatment of patients with thyroid cancer. In cases with distant metastases, RAI can cure one-third of the patients, but in other cases, it is not concentrated by the tumours or the tumours are resistant to RAI (Durante et al. 2006). An approach for the treatment of RAI-refractory patients is to re-enhance RAI uptake or to redifferentiate 
tumours. Restoring RAI uptake is indeed the first step of redifferentiation. It is mandatory, but to be clinically effective, it must be followed with anti-tumour effect. Recently, drugs targeting the MAPK pathway have been studied since the activation of the MAPK pathway is known to be associated with cell dedifferentiation and with a decrease in RAI uptake. In human BRAF-mutant PTCs, there is a low expression level of NIS and a low tumour differentiation score (Riesco-Eizaguirre et al. 2006, Romei et al. 2008, Fagin \& Wells 2016). In an engineered mouse model bearing the BRAFV600E mutation, thyroid cancer is insensitive to RAI treatment, and the treatment of these mice with small-molecule inhibitors of either MEK or mutant BRAFV600E reduces their proliferative index and partially restores thyroid-specific gene expression (Chakravarty et al. 2011). Based on these studies, MEK inhibitors and BRAF inhibitors have been developed for BRAF- and RAS-mutated TC patients. Pilot clinical studies in RAI-refractory patients showed an increase in the RAI avidity and tumour response following RAI treatment, when it was preceded by treatment with a MEK inhibitor (selumetinib) or a BRAF inhibitor (dabrafenib or vemurafenib) in patients with a $R A S$ or BRAFV600E mutation (Ho et al. 2013, Rothenberg et al. 2015, Dunn et al. 2018). Unfortunately, not all patients respond to these treatments, and further inhibition of the MAPK pathway with combination treatment is being investigated. Indeed, a strong inhibition of ERK signalling with potent anti-MEK drugs was shown to be essential to maximize BRAFV600E-thyroid cancer redifferentiation, providing a rationale for the combination of anti-BRAF and anti-MEK drugs in patients (Nagarajah et al. 2016). Clinical trials are underway with such a combination. Based on the understanding of oxidative stress in thyroid carcinoma that has been developed previously, future treatments with drugs targeting NOX4, as a single agent or in combination, have to be tested. Finally, the dedifferentiation of thyroid tumours is associated with an increase in the mutation burden, which might reflect the error-prone repair of oxidative DNA lesions. Tumour mutation burden has been demonstrated to be useful biomarker for immune checkpoint blockage across some cancer types. However, the mutation burden in thyroid cancer remains low compared to what is seen in lung cancer or melanoma. We have few data regarding response to immune checkpoint inhibitors at the moment.

\section{Declaration of interest}

Sophie Leboulleux declares a research grant from Novartis. The other authors have nothing to declare.

\section{Funding}

Dr Camille Buffet is the recipient of a grant from the Fondation de France (00067108). This work was supported by grants from Electricité de France (EDF) (RB2018-02), Fondation ARC (PJA2016/205007), Fondation de France (00067108), European Thyroid Association (ETA) (Research Grant) and Institut National du Cancer (INCA) (2013-1-PLBIO-14). This work was also supported in part by a donation of $\mathrm{Mr} \mathrm{G}$ Valle.

\section{Acknowledgements}

The authors thank Prof. Martin Schlumberger for his critical reading of the manuscript. They are very grateful to Dr Naïma Azouzi from Chromatin Biology Team, Department of Biosciences, University of Oslo, Norway, for her contribution in the analysis of TCGA data and to Dr Fabio Hecht from Laboratório de Fisiologia Endócrina Doris Rosenthal, Instituto de Biofísica Carlos Chagas Filho, Universidade Federal do Rio de Janeiro, Brazil for the scientific illustrations.

\section{References}

Akinci M, Kosova F, Cetin B, Sepici A, Altan N, Aslan S \& Cetin A 2008 Oxidant/antioxidant balance in patients with thyroid cancer. Acta Cirurgica Brasileira 23 551-554. (https://doi.org/10.1590/S0102$86502008000600013)$

Ameziane-El-Hassani R, Boufraqech M, Lagente-Chevallier O, Weyemi U, Talbot M, Metivier D, Courtin F, Bidart JM, El Mzibri M, Schlumberger M, et al. 2010 Role of H2O2 in RET/PTC1 chromosomal rearrangement produced by ionizing radiation in human thyroid cells. Cancer Research 70 4123-4132. (https://doi. org/10.1158/0008-5472.CAN-09-4336)

Ameziane-El-Hassani R, Talbot M, de Souza Dos Santos MC, Al Ghuzlan A, Hartl D, Bidart JM, De Deken X, Miot F, Diallo I, de Vathaire F, et al. 2015 NADPH oxidase DUOX1 promotes long-term persistence of oxidative stress after an exposure to irradiation. PNAS 112 5051-5056. (https://doi.org/10.1073/pnas.1420707112)

Ameziane-El-Hassani R, Schlumberger M \& Dupuy C 2016 NADPH oxidases: new actors in thyroid cancer? Nature Reviews Endocrinology 12 485-494. (https://doi.org/10.1038/nrendo.2016.64)

Antunes F \& Cadenas E 2000 Estimation of $\mathrm{H} 2 \mathrm{O} 2$ gradients across biomembranes. FEBS Letters 475 121-126. (https://doi.org/10.1016/ S0014-5793(00)01638-0)

Azouzi N, Cailloux J, Cazarin JM, Knauf JA, Cracchiolo J, Al Ghuzlan A, Hartl D, Polak M, Carre A, El Mzibri M, et al. 2017 NADPH oxidase NOX4 is a critical mediator of BRAF(V600E)-induced downregulation of the sodium/iodide symporter in papillary thyroid carcinomas. Antioxidants and Redox Signaling 26 864-877. (https://doi. org/10.1089/ars.2015.6616)

Bellelli R, Vitagliano D, Federico G, Marotta P, Tamburrino A, Salerno P, Paciello O, Papparella S, Knauf JA, Fagin JA, et al. 2018 Oncogeneinduced senescence and its evasion in a mouse model of thyroid neoplasia. Molecular and Cellular Endocrinology 460 24-35. (https:// doi.org/10.1016/j.mce.2017.06.023)

Berquist BR \& Wilson DM 2012 Pathways for repairing and tolerating the spectrum of oxidative DNA lesions. Cancer Letters 327 61-72. (https://doi.org/10.1016/j.canlet.2012.02.001)

Block K, Gorin Y \& Abboud HE 2009 Subcellular localization of Nox4 and regulation in diabetes. PNAS 106 14385-14390. (https://doi. org/10.1073/pnas.0906805106)

Boiteux S, Coste F \& Castaing B 2017 Repair of 8-oxo-7,8dihydroguanine in prokaryotic and eukaryotic cells: properties and biological roles of the Fpg and OGG1 DNA N-glycosylases. Free Radical Biology and Medicine 107 179-201. (https://doi.org/10.1016/j. freeradbiomed.2016.11.042) (c) 2019 Society for Endocrinology Published by Bioscientifica Ltd. Printed in Great Britain 
Bonora E, Porcelli AM, Gasparre G, Biondi A, Ghelli A, Carelli V, Baracca A, Tallini G, Martinuzzi A, Lenaz G, et al. 2006 Defective oxidative phosphorylation in thyroid oncocytic carcinoma is associated with pathogenic mitochondrial DNA mutations affecting complexes I and III. Cancer Research 66 6087-6096. (https://doi. org/10.1158/0008-5472.CAN-06-0171)

Boudreau HE, Casterline BW, Burke DJ \& Leto TL 2014 Wild-type and mutant p53 differentially regulate NADPH oxidase 4 in TGF-betamediated migration of human lung and breast epithelial cells. British Journal of Cancer 110 2569-2582. (https://doi.org/10.1038/ bjc.2014.165)

Burdon RH, Alliangana D \& Gill V 1995 Hydrogen peroxide and the proliferation of BHK-21. Free Radical Research 23 471-486. (https:// doi.org/10.3109/10715769509065268)

Cancer Genome Atlas Research Network 2014 Integrated genomic characterization of papillary thyroid carcinoma. Cell 159 676-690. (https://doi.org/10.1016/j.cell.2014.09.050)

Carre A, Louzada RAN, Fortunato RS, Ameziane-El-Hassani R, Morand S, Ogryzko V, de Carvalho DP, Grasberger H, Leto TL \& Dupuy C 2015 When an intramolecular disulfide bridge governs the interaction of DUOX2 with its partner DUOXA2. Antioxidants and Redox Signaling 23 724-733. (https://doi.org/10.1089/ars.2015.6265)

Carvalho DP \& Dupuy C 2017 Thyroid hormone biosynthesis and release. Molecular and Cellular Endocrinology 458 6-15. (https://doi. org/10.1016/j.mce.2017.01.038)

Chakravarty D, Santos E, Ryder M, Knauf JA, Liao XH, West BL, Bollag G, Kolesnick R, Thin TH, Rosen N, et al. 2011 Small-molecule MAPK inhibitors restore radioiodine incorporation in mouse thyroid cancers with conditional BRAF activation. Journal of Clinical Investigation 121 4700-4711. (https://doi.org/10.1172/JCI46382)

Coelho RG, Fortunato RS \& Carvalho DP 2018 Metabolic reprogramming in thyroid carcinoma. Frontiers in Oncology 882. (https://doi.org/10.3389/fonc.2018.00082)

Cremona CA \& Behrens A 2014 ATM signalling and cancer. Oncogene 33 3351-3360. (https://doi.org/10.1038/onc.2013.275)

De Deken X, Wang D, Many MC, Costagliola S, Libert F, Vassart G, Dumont JE \& Miot F 2000 Cloning of two human thyroid cDNAs encoding new members of the NADPH oxidase family. Journal of Biological Chemistry 275 23227-23233. (https://doi.org/10.1074/jbc. M000916200)

Detours V, Delys L, Libert F, Weiss Solis D, Bogdanova T, Dumont JE, Franc B, Thomas G \& Maenhaut C 2007 Genome-wide gene expression profiling suggests distinct radiation susceptibilities in sporadic and post-Chernobyl papillary thyroid cancers. British Journal of Cancer 97 818-825. (https://doi.org/10.1038/sj. bjc.6603938)

Dohan O, Baloch Z, Banrevi Z, Livolsi V \& Carrasco N 2001 Rapid communication: predominant intracellular overexpression of the $\mathrm{Na}(+) / \mathrm{I}(-)$ symporter (NIS) in a large sampling of thyroid cancer cases. Journal of Clinical Endocrinology and Metabolism 86 2697-2700. (https://doi.org/10.1210/jcem.86.6.7746)

Driessens N, Versteyhe S, Ghaddhab C, Burniat A, De Deken X, Van Sande J, Dumont JE, Miot F \& Corvilain B 2009 Hydrogen peroxide induces DNA single- and double-strand breaks in thyroid cells and is therefore a potential mutagen for this organ. Endocrine-Related Cancer 16 845-856. (https://doi.org/10.1677/ERC-09-0020)

Dunn LA, Sherman EJ, Baxi SS, Tchekmedyian V, Grewal RK, Larson SM, Pentlow KS, Haque S, Tuttle RM, Sabra MM, et al. 2018 Vemurafenib redifferentiation of BRAF mutant, RAI-refractory thyroid cancers. Journal of Clinical Endocrinology and Metabolism [epub]. (https://doi. org/10.1210/jc.2018-01478)

Dupuy C, Ohayon R, Valent A, Noel-Hudson MS, Deme D \& Virion A 1999 Purification of a novel flavoprotein involved in the thyroid NADPH oxidase. Cloning of the porcine and human cdnas. Journal of Biological Chemistry 274 37265-37269. (https://doi.org/10.1074/ jbc.274.52.37265)
Durante C, Haddy N, Baudin E, Leboulleux S, Hartl D, Travagli JP, Caillou B, Ricard M \& Lumbroso JD 2006 Long-term outcome of 444 patients with distant metastases from papillary and follicular thyroid carcinoma: benefits and limits of radioiodine therapy. Journal of Clinical Endocrinology and Metabolism 91 2892-2899. (https://doi. org/10.1210/jc.2005-2838)

Fagin JA \& Wells SA, Jr 2016 Biologic and clinical perspectives on thyroid cancer. New England Journal of Medicine 375 2307. (https:// doi.org/10.1056/NEJMc1613118)

Fagin JA, Matsuo K, Karmakar A, Chen DL, Tang SH \& Koeffler HP 1993 High prevalence of mutations of the p53 gene in poorly differentiated human thyroid carcinomas. Journal of Clinical Investigation 91 179-184. (https://doi.org/10.1172/JCI116168)

Fortunato RS, Lima de Souza EC, Ameziane-el Hassani R, Boufraqech M, Weyemi U, Talbot M, Lagente-Chevallier O, de Carvalho DP, Bidart JM, Schlumberger M, et al. 2010 Functional consequences of dual oxidase-thyroperoxidase interaction at the plasma membrane. Journal of Clinical Endocrinology and Metabolism 95 5403-5411. (https://doi.org/10.1210/jc.2010-1085)

Gandhi M, Dillon LW, Pramanik S, Nikiforov YE \& Wang YH 2010 DNA breaks at fragile sites generate oncogenic RET/PTC rearrangements in human thyroid cells. Oncogene 29 2272-2280. (https://doi. org/10.1038/onc.2009.502)

Geric M, Domijan AM, Gluscic V, Janusic R, Sarcevic B \& GarajVrhovac V 2016 Cytogenetic status and oxidative stress parameters in patients with thyroid diseases. Mutation Research 810 22-29. (https://doi.org/10.1016/j.mrgentox.2016.09.010)

Grasberger H \& Refetoff S 2006 Identification of the maturation factor for dual oxidase. Evolution of an eukaryotic operon equivalent. Journal of Biological Chemistry 281 18269-18272. (https://doi. org/10.1074/jbc.C600095200)

Hasegawa Y, Takano T, Miyauchi A, Matsuzuka F, Yoshida H, Kuma K \& Amino N 2002 Decreased expression of glutathione peroxidase mRNA in thyroid anaplastic carcinoma. Cancer Letters 182 69-74. (https://doi.org/10.1016/S0304-3835(02)00069-1)

Hasegawa Y, Takano T, Miyauchi A, Matsuzuka F, Yoshida H, Kuma K \& Amino N 2003 Decreased expression of catalase mRNA in thyroid anaplastic carcinoma. Japanese Journal of Clinical Oncology 33 6-9. (https://doi.org/10.1093/jjco/hyg009)

Haymart MR, Glinberg SL, Liu J, Sippel RS, Jaume JC \& Chen H 2009 Higher serum TSH in thyroid cancer patients occurs independent of age and correlates with extrathyroidal extension. Clinical Endocrinology 71 434-439. (https://doi. org/10.1111/j.1365-2265.2008.03489.x)

Helleday T, Eshtad S \& Nik-Zainal S 2014 Mechanisms underlying mutational signatures in human cancers. Nature Reviews Genetics 15 585-598. (https://doi.org/10.1038/nrg3729)

Ho AL, Grewal RK, Leboeuf R, Sherman EJ, Pfister DG, Deandreis D, Pentlow KS, Zanzonico PB, Haque S, Gavane S, et al. 2013 Selumetinib-enhanced radioiodine uptake in advanced thyroid cancer. New England Journal of Medicine 368 623-632. (https://doi. org/10.1056/NEJMoa1209288)

Hodis E, Watson IR, Kryukov GV, Arold ST, Imielinski M, Theurillat JP, Nickerson E, Auclair D, Li L, Place C, et al. 2012 A landscape of driver mutations in melanoma. Cell 150 251-263. (https://doi. org/10.1016/j.cell.2012.06.024)

Holmström KM \& Finkel T 2014 Cellular mechanisms and physiological consequences of redox-dependent signalling. Nature Reviews: Molecular Cell Biology 15 411-421. (https://doi.org/10.1038/nrm3801)

Hu S, Zhang G, Xu J, Zhu X, Lu X, Jiang L, Wang Q, Hou X, Cao J \& Ge M 2014 Disparity expression of gammaH2AX in papillary thyroid cancer and nodular goiter. Clinical Laboratory 60 2031-2037. (https:// doi.org/10.7754/Clin.Lab.2014.140603)

Huang BK \& Sikes HD 2014 Quantifying intracellular hydrogen peroxide perturbations in terms of concentration. Redox Biology 2 955-962. (https://doi.org/10.1016/j.redox.2014.08.001) 
Karger S, Krause K, Engelhardt C, Weidinger C, Gimm O, Dralle H, Sheu-Grabellus SY, Schmid KW \& Fuhrer D 2012 Distinct pattern of oxidative DNA damage and DNA repair in follicular thyroid tumours. Journal of Molecular Endocrinology 48 193-202. (https://doi. org/10.1530/JME-11-0119)

Kasai H 1997 Analysis of a form of oxidative DNA damage, 8-hydroxy2 '-deoxyguanosine, as a marker of cellular oxidative stress during carcinogenesis. Mutation Research 387 147-163. (https://doi. org/10.1016/S1383-5742(97)00035-5)

Kim H, Lee TH, Park ES, Suh JM, Park SJ, Chung HK, Kwon OY, Kim YK, Ro HK \& Shong M 2000 Role of peroxiredoxins in regulating intracellular hydrogen peroxide and hydrogen peroxide-induced apoptosis in thyroid cells. Journal of Biological Chemistry 275 18266-18270. (https://doi.org/10.1074/jbc.275.24.18266)

Knauf JA, Sartor MA, Medvedovic M, Lundsmith E, Ryder M, Salzano M, Nikiforov YE, Giordano TJ, Ghossein RA \& Fagin JA 2011 Progression of BRAF-induced thyroid cancer is associated with epithelial-mesenchymal transition requiring concomitant MAP kinase and TGFbeta signaling. Oncogene $303153-3162$. (https://doi. org/10.1038/onc.2011.44)

Kohrle J \& Gartner R 2009 Selenium and thyroid. Best Practice and Research: Clinical Endocrinology and Metabolism 23 815-827. (https:// doi.org/10.1016/j.beem.2009.08.002)

Krohn K, Maier J \& Paschke R 2007 Mechanisms of disease: hydrogen peroxide, DNA damage and mutagenesis in the development of thyroid tumors. Nature Clinical Practice: Endocrinology and Metabolism 3 713-720. (https://doi.org/10.1038/ncpendmet0621)

Lacroix L, Nocera M, Mian C, Caillou B, Virion A, Dupuy C, Filetti S, Bidart JM \& Schlumberger M 2001 Expression of nicotinamide adenine dinucleotide phosphate oxidase flavoprotein DUOX genes and proteins in human papillary and follicular thyroid carcinomas. Thyroid 11 1017-1023. (https://doi. org/10.1089/105072501753271699)

Landa I, Ibrahimpasic T, Boucai L, Sinha R, Knauf JA, Shah RH, Dogan S, Ricarte-Filho JC, Krishnamoorthy GP, Xu B, et al. 2016 Genomic and transcriptomic hallmarks of poorly differentiated and anaplastic thyroid cancers. Journal of Clinical Investigation 126 1052-1066. (https://doi.org/10.1172/JCI85271)

Louzada RA, Corre R, Ameziane-El-Hassani R, Hecht F, Cazarin J, Buffet C, Carvalho DP \& Dupuy C 2018 Conformation of the N-terminal ectodomain elicits different effects on DUOX function: a potential impact on congenital hypothyroidism caused by a $\mathrm{H} 2 \mathrm{O} 2$ production defect. Thyroid 28 1052-1062. (https://doi.org/10.1089/ thy.2017.0596)

Lukosz M, Jakob S, Buchner N, Zschauer TC, Altschmied J \& Haendeler J 2010 Nuclear redox signaling. Antioxidants and Redox Signaling 12 713-742. (https://doi.org/10.1089/ars.2009.2609)

Maier J, van Steeg H, van Oostrom C, Karger S, Paschke R \& Krohn K 2006 Deoxyribonucleic acid damage and spontaneous mutagenesis in the thyroid gland of rats and mice. Endocrinology 147 3391-3397. (https://doi.org/10.1210/en.2005-1669)

Martinez-Cadenas C, Bosch N, Penas L, Flores-Couce E, Ochoa E, Munarriz J, Aracil JP, Tajahuerce M, Royo R, Lozoya R, et al. 2011 Malignant melanoma arising from a perianal fistula and harbouring a BRAF gene mutation: a case report. BMC Cancer 11 343. (https:// doi.org/10.1186/1471-2407-11-343)

Matoba H, Sugano S, Yamaguchi N \& Miyachi Y 1998 Expression of transforming growth factor-beta1 and transforming growth factorbeta Type-II receptor mRNA in papillary thyroid carcinoma. Hormone and Metabolic Research 30 624-628.

Meng TC, Fukada T \& Tonks NK 2002 Reversible oxidation and inactivation of protein tyrosine phosphatases in vivo. Molecular Cell 9 387-399. (https://doi.org/10.1016/S1097-2765(02)00445-8)

Metere A, Chiesa C, Di Cosimo C, Fierro G, Giacomelli L \& Pietraforte D 2012 A novel approach to study oxidative stress in thyroid diseases: a preliminary study. European Review for Medical and Pharmacological Sciences 16 646-652.

Metere A, Frezzotti F, Graves CE, Vergine M, De Luca A, Pietraforte D \& Giacomelli L 2018 A possible role for selenoprotein glutathione peroxidase (GPx1) and thioredoxin reductases (TrxR1) in thyroid cancer: our experience in thyroid surgery. Cancer Cell International 18 7. (https://doi.org/10.1186/s12935-018-0504-4)

Nagarajah J, Le M, Knauf JA, Ferrandino G, Montero-Conde C, Pillarsetty N, Bolaender A, Irwin C, Krishnamoorthy GP, Saqcena M, et al. 2016 Sustained ERK inhibition maximizes responses of BrafV600E thyroid cancers to radioiodine. Journal of Clinical Investigation 126 4119-4124. (https://doi.org/10.1172/JCI89067)

Nakashima M, Suzuki K, Meirmanov S, Naruke Y, Matsuu-Matsuyama M, Shichijo K, Saenko V, Kondo H, Hayashi T, Ito M, et al. 2008 Foci formation of P53-binding protein 1 in thyroid tumors: activation of genomic instability during thyroid carcinogenesis. International Journal of Cancer 122 1082-1088. (https://doi.org/10.1002/ijc.23223)

Nicolussi A, D’Inzeo S, Mincione G, Buffone A, Di Marcantonio MC, Cotellese R, Cichella A, Capalbo C, Di Gioia C, Nardi F, et al. 2014 PRDX1 and PRDX6 are repressed in papillary thyroid carcinomas via BRAF V600E-dependent and -independent mechanisms. International Journal of Oncology 44 548-556. (https://doi.org/10.3892/ ijo.2013.2208)

Nicolussi A, D'Inzeo S, Capalbo C, Giannini G \& Coppa A 2017 The role of peroxiredoxins in cancer. Molecular and Clinical Oncology 6 139-153. (https://doi.org/10.3892/mco.2017.1129)

Puppin C, Arturi F, Ferretti E, Russo D, Sacco R, Tell G, Damante G \& Filetti S 2004 Transcriptional regulation of human sodium/iodide symporter gene: a role for redox factor-1. Endocrinology 145 1290-1293. (https://doi.org/10.1210/en.2003-1250)

Richardson C \& Jasin M 2000 Frequent chromosomal translocations induced by DNA double-strand breaks. Nature 405 697-700. (https:// doi.org/10.1038/35015097)

Riesco-Eizaguirre G, Gutierrez-Martinez P, Garcia-Cabezas MA, Nistal M \& Santisteban P 2006 The oncogene BRAF V600E is associated with a high risk of recurrence and less differentiated papillary thyroid carcinoma due to the impairment of $\mathrm{Na}+/ \mathrm{I}-$ targeting to the membrane. Endocrine-Related Cancer 13 257-269. (https://doi. org/10.1677/erc.1.01119)

Riesco-Eizaguirre G, Rodriguez I, De la Vieja A, Costamagna E, Carrasco N, Nistal M \& Santisteban P 2009 The BRAFV600E oncogene induces transforming growth factor beta secretion leading to sodium iodide symporter repression and increased malignancy in thyroid cancer. Cancer Research 69 8317-8325. (https://doi. org/10.1158/0008-5472.CAN-09-1248)

Rigutto S, Hoste C, Grasberger H, Milenkovic M, Communi D, Dumont JE, Corvilain B, Miot F \& De Deken X 2009 Activation of dual oxidases Duox1 and Duox2: differential regulation mediated by camp-dependent protein kinase and protein kinase C-dependent phosphorylation. Journal of Biological Chemistry 284 6725-6734. (https://doi.org/10.1074/jbc.M806893200)

Robbins ME \& Zhao W 2004 Chronic oxidative stress and radiationinduced late normal tissue injury: a review. International Journal of Radiation Biology 80 251-259. (https://doi.org/10.1080/09553000410 001692726)

Romei C, Ciampi R, Faviana P, Agate L, Molinaro E, Bottici V, Basolo F, Miccoli P, Pacini F, Pinchera A, et al. 2008 BRAFV600E mutation, but not RET/PTC rearrangements, is correlated with a lower expression of both thyroperoxidase and sodium iodide symporter genes in papillary thyroid cancer. Endocrine-Related Cancer 15 511-520. (https://doi.org/10.1677/ERC-07-0130)

Rothenberg SM, McFadden DG, Palmer EL, Daniels GH \& Wirth LJ 2015 Redifferentiation of iodine-refractory BRAF V600E-mutant metastatic papillary thyroid cancer with dabrafenib. Clinical Cancer Research 21 1028-1035. (https://doi.org/10.1158/1078-0432.CCR-14-2915) https://erc.bioscientifica.com

https://doi.org/10.1530/ERC-18-0476 (c) 2019 Society for Endocrinology Published by Bioscientifica Ltd. Printed in Great Britain 
Scott TL, Rangaswamy S, Wicker CA \& Izumi T 2014 Repair of oxidative DNA damage and cancer: recent progress in DNA base excision repair. Antioxidants and Redox Signaling 20 708-726. (https://doi. org/10.1089/ars.2013.5529)

Sedelnikova OA, Redon CE, Dickey JS, Nakamura AJ, Georgakilas AG \& Bonner WM 2010 Role of oxidatively induced DNA lesions in human pathogenesis. Mutation Research 704 152-159. (https://doi. org/10.1016/j.mrrev.2009.12.005)

Shanmugasundaram K, Nayak BK, Friedrichs WE, Kaushik D, Rodriguez R \& Block K 2017 NOX4 functions as a mitochondrial energetic sensor coupling cancer metabolic reprogramming to drug resistance. Nature Communications 8 997. (https://doi.org/10.1038/ s41467-017-01106-1)

Sies H 2017 Hydrogen peroxide as a central redox signaling molecule in physiological oxidative stress: oxidative eustress. Redox Biology 11 613-619. (https://doi.org/10.1016/j.redox.2016.12.035)

Sinnott B, Ron E \& Schneider AB 2010 Exposing the thyroid to radiation: a review of its current extent, risks, and implications. Endocrine Reviews 31 756-773. (https://doi.org/10.1210/er.2010-0003)

Smith VE, Sharma N, Watkins RJ, Read ML, Ryan GA, Kwan PP, Martin A, Watkinson JC, Boelaert K, Franklyn JA, et al. 2013 Manipulation of PBF/PTTG1IP phosphorylation status; a potential new therapeutic strategy for improving radioiodine uptake in thyroid and other tumors. Journal of Clinical Endocrinology and Metabolism 98 2876-2886. (https://doi.org/10.1210/jc.2012-3640)

Song Y, Ruf J, Lothaire P, Dequanter D, Andry G, Willemse E, Dumont JE, Van Sande J \& De Deken X 2010 Association of duoxes with thyroid peroxidase and its regulation in thyrocytes. Journal of Clinical Endocrinology and Metabolism 95 375-382. (https://doi. org/10.1210/jc.2009-1727)

Tam AA, Ozdemir D, Aydin C, Bestepe N, Ulusoy S, Sungu N, Ersoy R \& Cakir B 2018 Association between preoperative thyrotrophin and clinicopathological and aggressive features of papillary thyroid cancer. Endocrine 59 565-572. (https://doi.org/10.1007/s12020-0181523-6)

Tubbs A \& Nussenzweig A 2017 Endogenous DNA damage as a source of genomic instability in cancer. Cell 168 644-656. (https://doi. org/10.1016/j.cell.2017.01.002)

Valdiglesias V, Giunta S, Fenech M, Neri M \& Bonassi S 2013 gammaH2AX as a marker of DNA double strand breaks and genomic instability in human population studies. Mutation Research $\mathbf{7 5 3}$ 24-40. (https://doi.org/10.1016/j.mrrev.2013.02.001)

Valko M, Rhodes CJ, Moncol J, Izakovic M \& Mazur M 2006 Free radicals, metals and antioxidants in oxidative stress-induced cancer. Chemico-Biological Interactions 160 1-40. (https://doi.org/10.1016/j. cbi.2005.12.009)

Vasko V, Espinosa AV, Scouten W, He H, Auer H, Liyanarachchi S, Larin A, Savchenko V, Francis GL, de la Chapelle A, et al. 2007 Gene expression and functional evidence of epithelial-to-mesenchymal transition in papillary thyroid carcinoma invasion. PNAS $\mathbf{1 0 4}$ 2803-2808. (https://doi.org/10.1073/pnas.0610733104)

Veal EA, Day AM \& Morgan BA 2007 Hydrogen peroxide sensing and signaling. Molecular Cell 26 1-14. (https://doi.org/10.1016/j. molcel.2007.03.016)

Versteyhe S, Driessens N, Ghaddhab C, Tarabichi M, Hoste C, Dumont JE, Miot F, Corvilain B \& Detours V 2013 Comparative analysis of the thyrocytes and T cells: responses to $\mathrm{H} 2 \mathrm{O} 2$ and radiation reveals an $\mathrm{H} 2 \mathrm{O} 2$-induced antioxidant transcriptional program in thyrocytes. Journal of Clinical Endocrinology and Metabolism 98 E1645-E1654. (https://doi.org/10.1210/jc.2013-1266)

Viglietto G, Chiappetta G, Martinez-Tello FJ, Fukunaga FH, Tallini G, Rigopoulou D, Visconti R, Mastro A, Santoro M \& Fusco A 1995 RET/PTC oncogene activation is an early event in thyroid carcinogenesis. Oncogene 11 1207-1210.

Vizioli MG, Possik PA, Tarantino E, Meissl K, Borrello MG, Miranda C, Anania MC, Pagliardini S, Seregni E, Pierotti MA, et al. 2011 Evidence of oncogene-induced senescence in thyroid carcinogenesis. Endocrine-Related Cancer 18 743-757. (https://doi.org/10.1530/ERC11-0240)

Vizioli MG, Santos J, Pilotti S, Mazzoni M, Anania MC, Miranda C, Pagliardini S, Pierotti MA, Gil J \& Greco A 2014 Oncogenic RASinduced senescence in human primary thyrocytes: molecular effectors and inflammatory secretome involved. Oncotarget 5 8270-8283. (https://doi.org/10.18632/oncotarget.2013)

Wang D, Kreutzer DA \& Essigmann JM 1998 Mutagenicity and repair of oxidative DNA damage: insights from studies using defined lesions. Mutation Research 400 99-115. (https://doi.org/10.1016/S00275107(98)00066-9)

Wang D, Feng JF, Zeng P, Yang YH, Luo J \& Yang YW 2011 Total oxidant/antioxidant status in sera of patients with thyroid cancers. Endocrine-Related Cancer 18 773-782. (https://doi.org/10.1530/ERC11-0230)

Weyemi U, Caillou B, Talbot M, Ameziane-El-Hassani R, Lacroix L, Lagent-Chevallier O, Al Ghuzlan A, Roos D, Bidart JM, Virion A, et al. 2010 Intracellular expression of reactive oxygen speciesgenerating NADPH oxidase NOX4 in normal and cancer thyroid tissues. Endocrine-Related Cancer 17 27-37. (https://doi.org/10.1677/ ERC-09-0175)

Weyemi U, Lagente-Chevallier O, Boufraqech M, Prenois F, Courtin F, Caillou B, Talbot M, Dardalhon M, Al Ghuzlan A, Bidart JM, et al. 2012 ROS-generating NADPH oxidase NOX4 is a critical mediator in oncogenic H-Ras-induced DNA damage and subsequent senescence. Oncogene 31 1117-1129. (https://doi.org/10.1038/onc.2011.327)

Xing M 2013 BRAF V600E mutation and papillary thyroid cancer. JAMA 310 535. (https://doi.org/10.1001/jama.2013.8592)

Xu B, Wang W, Guo H, Sun Z, Wei Z, Zhang X, Liu Z, Tischfield JA, Gong Y \& Shao C 2014 Oxidative stress preferentially induces a subtype of micronuclei and mediates the genomic instability caused by p53 dysfunction. Mutation Research 770 1-8. (https://doi. org/10.1016/j.mrfmmm.2014.08.004)

Young O, Crotty T, O'Connell R, O'Sullivan J \& Curran AJ 2010 Levels of oxidative damage and lipid peroxidation in thyroid neoplasia. Head and Neck 32 750-756. (https://doi.org/10.1002/hed.21247)

Zeman MK \& Cimprich KA 2014 Causes and consequences of replication stress. Nature Cell Biology 16 2-9. (https://doi. org/10.1038/ncb2897)

Zlatanou A, Despras E, Braz-Petta T, Boubakour-Azzouz I, Pouvelle C, Stewart GS, Nakajima S, Yasui A, Ishchenko AA \& Kannouche PL 2011 The hMsh2-hMsh6 complex acts in concert with monoubiquitinated PCNA and Pol eta in response to oxidative DNA damage in human cells. Molecular Cell 43 649-662. (https://doi. org/10.1016/j.molcel.2011.06.023)

Received in final form 4 January 2019

Accepted 7 January 2019

Accepted Preprint published online 7 January 2019 https://erc.bioscientifica.com https://doi.org/10.1530/ERC-18-0476 (c) 2019 Society for Endocrinology Published by Bioscientifica Ltd. Printed in Great Britain 